\title{
Spousal Social Emotional Support for Businessman Based on Demographic Factors
}

\author{
Jimmy Ellya Kurniawan, Ersa Lanang Sanjaya \\ School of Psychology, Ciputra University, Surabaya, Indonesia \\ Email: jimmy.ellya@ciputra.ac.id
}

How to cite this paper: Kurniawan, J.E. and Sanjaya, E.L. (2017) Spousal Social Emotional Support for Businessman Based on Demographic Factors. Open Journal of Social Sciences, 5, 283-289. https://doi.org/10.4236/jss.2017.57017

Received: June 27, 2017

Accepted: July 17, 2017

Published: July 20, 2017

Copyright ( 92017 by authors and Scientific Research Publishing Inc. This work is licensed under the Creative Commons Attribution-NonCommercial International License (CC BY-NC 4.0). http://creativecommons.org/licenses/by-nc/4.0/ (c) (i) (8) Open Access

\begin{abstract}
Previous studies show that spousal social emotional support has a strong impact on businessman's efficacy. Spousal social emotional support is not solely influenced by the businessman's strategies of marital relationship, but also associated with demographic factors, such as working period, marital duration, and number of children. The purpose of this study was to investigate the association between demographic factors with spousal social emotional support. Research conducted at 61 married businessmen in Surabaya, Indonesia. Hypotheses in this study were tested with Spearman's rho. The results of this study indicate that both the marital duration and the number of children have no association with spousal social emotional support. While the working period has negative association with spousal social emotional support. Some argumentations are discussed further in this study.
\end{abstract}

\section{Keywords}

Spousal, Support, Businessman, Demographic

\section{Introduction}

In the daily work of a businessman, it requires social emotional support from the wife to manage stress and improve the efficacy of his business [1]. Based on the results of research Kurniawan and Sanjaya [1] spousal social emotional support has a strong positive influence on businessman's efficacy. Emotional social support is spousal support in information or feedback that can strengthen the husband's business-efficacy [2]. In their study, Kurniawan and Sanjaya [1] described marital relation strategies as antecedent of spousal social emotional support, but had not tested its association with demographic factors.

In the industry context, organizational support can be influenced by job satisfaction. The higher the employee's job satisfaction is, the stronger the support 
for the organization is [3]. While job satisfaction is influenced by demographic factors such as age, sex, marital status, and years of service [4], in the context of marriage relationships can also be assumed that spousal social emotional support is also influenced by demographic factors through marital satisfaction. The purpose of this study was to investigate the association between demographics factors with businessman's spousal social emotional support. There are three demographics factors to be tested in this study, namely working period, marital duration and number of children.

\section{Review of Literature}

Previous studies were more focus on spousal social emotional support for businessman without discussed about the demographic factors [1] [2]. This study was innovating with discover the demographics factors that probably influence the spousal social emotional support.

\subsection{Spousal Emotional Social Support}

Spousal emotional social support can either increase or inhibit energy for an entrepreneur or businessman. Such support can transmit stress effects in a timelimited. Positive emotional social support from a spouse will be shown through a willingness to share feelings and provide feedback to her husband about the business problem he is facing. A businessman who gets positive support from his spouse will be confident he can stay strong in his business when conditions are bad. In contrast, the negative support from his spouse is indicated by the lack of acceptance of feelings and lack of feedback from spouse on her husband's business. A businessman who gets a negative support from his spouse will drain his energy so that a businessman feels his business condition will get worse [2].

\subsection{Working Period}

The longer of working period make someone will be more committed, productive and satisfied with his work [4]. Businessman working periods include prelaunch, launch and post-launch, which is the longer the business can survive the more complex businessman involvement in its work [5] [6]. The number of hours of work per week is often associated inversely with the amount of time spent on household chores or quality interaction at home [7]. Similarly, the longer the businessman run his business then the number of hours work per week that have to spend because the more complex of his work.

\subsection{Marital Duration}

The many of pressures, the number of family problems, the lack of interaction, and the lack of support for marital relationships, make marital duration negatively correlated with marital happiness. In the early years of married couples strive to adjust and hope in the following years they will be more able to adjust to each other. But the fact is that as time goes by their characters are also mu- 
tually changing and unable to meet their previous expectations so that it further reduces their marital happiness [8]. Another study proves that boredom marriage in year 7 can predict reduced marital satisfaction significance at year 16 [9]. Research in United States, United Kingdom \& Turkey also showed that duration of married was negatively predict marital satisfaction [10].

\subsection{Number of Children}

Research in the United States, British \& Turkey also shows that number of children was negatively predicted marital satisfaction. The greater number of children it will diminish the perception of husband's love or wife's love [10]. Other studies in the United States also show that the number of children was decrease marital happiness, especially for the first 25 years of the marriage [8].

\subsection{Spousal Social Emotional Support Based on Demographic Factors}

Demographic factors in this study, working period, marital duration and number of children, have an impact on marital happiness or marital satisfaction. At the organizational context, job satisfaction has positive effect toward willingness to support organization [3]. At the family context, also assumed that wife marital satisfaction will positively effect toward support for her husband's business.

The longer the working period of a businessman in running his business then he will be increasingly involved in the business. The more busy a businessman is then assumed to decrease the amount of time spent on household chores or quality interaction at home. Many argue that an increasingly busy husband will reduce wife's marital satisfaction [7]. Based on research on organizational context [3], also assumed that wife marital satisfaction will positively effect toward support for her husband's business. Unsatisfaction of married will make spouse so reluctant to give emotional social-support to her husband in running his business, and vice versa. H1: Working period in business has association with spousal social emotional support.

Duration of married was negatively predicted marital happiness and marital satisfaction [8] [10]. Based on re-search on organizational context [3], also assumed that wife marital satisfaction will positively effect toward support for her husband's business. Unhappy and unsatisfaction of married will make spouse so reluctant to give emotional social-support to her husband in running his business, and vice versa. H2: Marital duration of businessman has association with spousal social emotional support.

The number of children was decreased by marital happiness and marital satisfaction [8] [10]. Based on research on organizational context [3], also assumed that wife marital satisfaction will positively effect toward support for her husband's business. Unhappy and unsatisfaction of married will make spouse so reluctant to give emotional social-support to her husband in running his business, and vice versa. H3: Number of businessman's children has association with spousal social emotional support. 


\section{Method}

\subsection{Participants}

This study used non-random sampling method. The survey distributed by online toward around 75 businessmen in Surabaya and the surrounding areas. But only 61 subjects had well respond the survey. Based on that the subjects of this study were 61 male businessmen under 45 years old. They have married, domiciled in Surabaya and other areas surround the city. They have working or business period between 1 until more than 10 years. Twenty-seven businessmen have working period for 1 - 5 years, 20 businessmen have working period for 6 - 10 years, and 14 businessmen have working period for more than 10 years. They have marital duration between 1 until more than 10 years. Twenty-two businessmen have been married for $1-5$ years, 15 businessmen have been married for 6 - 10 years and the rest have been married over than 10 years. They have number of children between no child until six children. Seven businessmen have no child, 15 businessmen have only one child, 23 businessmen have two children, 12 businessmen have three children, and 3 businessmen have four children and rest of them have six children.

\subsection{Research Tools}

This research used a questionnaire in Bahasa Indonesia. Tryout of this questionnaire has already done on thirty intrapreneurs before this study. The unidimensional scale of spousal social emotional support has three items. It was modified from Danes, Matzek \& Werbel [2]. That scale used Likert format with five points or answer options. The answers options were put on the range "strongly disagree" for score 1 until "strongly agree" for score 5. The Cronbach Alpha reliability of that scale is $\alpha=0.870$. The example item is, "I've got more release after share my business problem to my spouse".

Demographics data was gotten by open questionnaire. Participants were asked to fill in data of working period, marital duration and number of children on the questionnaire that put on the page before the scale of spousal social emotional support.

\subsection{Analysis}

The three of hypotheses on this study was tested by Spearman's Rho Correlation. Previous those hypotheses test, the distribution data was tested by Kolmogorov-Smirnov.

\section{Results}

Based on Kolmogorov-Smirnov Test, the results of normality data test are as showed on Table 1.

The results on Table 1 indicate that the data of spousal social emotional support as the dependent variable has abnormal distribution. Thus, the three of hypotheses on this study was tested by Spearman's Rho Correlation. 
Table 1. Distribution Data Test.

\begin{tabular}{cccc}
\hline Variable & $\mathrm{Z}$ & $\mathrm{p}$-Value $\left.{ }^{\star}\right)$ & Distribution \\
\hline Spousal social Emotional Support & 2.493 & 0.000 & Abnormal \\
Working Period & 1.106 & 0.173 & Normal \\
Marital Duration & 1.064 & 0.207 & Normal \\
Number of Children & 1.552 & 0.016 & Abnormal \\
\hline
\end{tabular}

*) Significant for Two Tail Analysis $(\mathrm{p}<0.05)$.

Table 2. Hypotheses Test.

\begin{tabular}{cccc}
\hline Hypothesis & Rho & p-Value ${ }^{\star}$ & Result \\
\hline H1 & -0.298 & 0.012 & Accepted \\
H2 & -0.160 & 0.115 & Rejected \\
H3 & 0.046 & 0.362 & Rejected \\
\hline
\end{tabular}

*) Significant for Two Tail Analysis $(\mathrm{p}<0.05)$.

The results on Table 2 indicate that only working period has weak significant negative association with spousal social emotional support. There was not significant association between marital duration and spousal social emotional support. Also, number of children was not significant association with spousal social emotional support.

\section{Discussion}

H1: Working period in business has association with spousal social emotional support has accepted with negative association. The longer of working period, the weaker of spousal social emotional support. Businessman who runs longer business will be more and more involved with various complex business processes. Even businessmen who are already in the post-launch phase will begin to exit strategy, which is preparing a replacement to manage their current business and getting ready to grow its new business so he's getting more busy [5]. The more time a husband spends in running or growing his business the less time spent on household chores or quality interaction at home thus reduces wife's marital satisfaction [7]. Based on research on organizational context [3], also assumed that wife marital satisfaction will positively effect toward support for her husband's business. Unsatisfaction of married will make spouse so reluctant to give emotional social-support to her husband in running his business, and vice versa. Thus the longer the husband runs his business, the weaker the spousal social emotional support.

H2: Marital duration of businessman has association with spousal social emotional support has rejected. Research in the United States, United Kingdom \& Turkey showing that duration of married was negatively predict marital satisfaction [10] can not be argued against the results of this study. Other results indicate that marital duration is not always straight correlate to marital happiness, 
but rather to form a U-shape curve [8]. This study only tests the associations so that the possibility of $U$-shape curves will be interpreted as unrelated. The longer marital duration also makes the couple more able to adapt and manage the conflict so as to increase the satisfaction of his marriage. Based on research on organizational context [3], also assumed that wife marital satisfaction will positively effect toward support for her husband's business. While the results of the study show that there's not always straight correlation between marital duration with marital happiness or satisfaction so that consequence also does not bring effect to spousal social-emotional support.

H3: The number of businessman's children has association with spousal social emotional support has rejected. Number of children does not always have negative correlation with the marital satisfaction. The desired number of children can also be influenced by various perception of children values. Research results in Indonesia show that the desire to increase the number of children also influenced by their perception of children values, such as primary group ties and affection, adult status and social identity and economic utility [11]. Probably some businessmen in this study had wives with that perception of children values and some others did not have that perception, but that has not been specific measured in this study. As result number of children not necessarily affect the marital satisfaction that ultimately also does not affect the spousal social-emotional support.

\section{Conclusions}

This study proves that only working period in business has association with spousal social emotional support. Marital duration of businessman has no association with spousal social emotional support. Number of businessman's children has no association with spousal social emotional support.

The limitation of this study was not investigated by regression test thus the result can't describe the form of effect between variables, such as linear or curve relation. This study didn't investigate the parent's perception of children values as well thus the result can't describe the specific psychological dynamics of marriage couple about their number of children.

Future studies are recommended to use regression test in order to know more specific forms of effect between variables. The perception of children values also needs to be involved as a variable in the next research to know more specifically about the psychological dynamics in it.

\section{Acknowledgements}

We acknowledge the support and generosity of Kemenristek Dikti Republic of Indonesia that supported with Penelitian Hibah Bersaing (PHB)/Penelitian Produk Terapan (PPT) 2017 for this research.

\section{References}

[1] Kurniawan, J.E. and Sanjaya, E.L. (2016) The Role of Marital Relation Strategies on 
Business Efficacy of Young Male Entrepreneurs with Spousal Involvement and Support as Mediators. Open Journal of Social Sciences, 4, 56-66. https://doi.org/10.4236/jss.2016.49007

[2] Danes, S.M., Matzek, A.E. and Werbel, J.D. (2010) Spousal Context during the Venture Creation Process. Entrepreneurship and Family Business: Advances in Entrepreneurship, Firm Emergence and Growth, 12, 113-161. https://doi.org/10.1108/S1074-7540(2010)0000012007

[3] Tsachouridi, I. and Nikandrou, I. (2016) Breach and Willingness to Support the Organization: An Attribution and Social Exchange Perspective. Management Research Review, 39, 1336-1351. https://doi.org/10.1108/MRR-06-2015-0148

[4] Robbins, S.P. and Judge, T.A. (2011) Organizational Behavior (Perilaku Organisasi). Salemba Empat.

[5] Leon, J.A.M. and Gorgievski, M. (2007) Psychology of Entrepreneurship: Research and Education. Universidad Nacional De Educacion A Distancia.

[6] Baum, J.R., Frese, M. and Baron, R. (2012) The Psychology of Entrepreneurship. LEA Publishers, London.

[7] Barling, J. (1984) Effects of Husband's Work Experiences on Wive's Marital Satisfaction. The Journal of Social Psychology, 124, 219-225.

https://doi.org/10.1080/00224545.1984.9922850

[8] Van Laningham, J., Johnson, D.R. and Amato, P. (2001) Marital Happiness, Marital Duration and the U-Shaped Curve: Evidence from a Five-Wave Panel Study. Social Forces, 78, 1313-1341. https://doi.org/10.1353/sof.2001.0055

[9] Tsapelas, I., Aron, A. and Orbuch, T. (2009) Marital Boredom Now Predicts Less Satisfaction 9 Years Later. Psychological Science, 20, 543-545.

http://www.jstor.org/stable/40575060 https://doi.org/10.1111/j.1467-9280.2009.02332.x

[10] Wendorf, C.A., Lucas, T., Imamoglu, E.O., Weisfeld, C.C. and Weisfeld, G.E. (2010) Marital Satisfaction across Three Cultures: Does the Number of Children Have an Impact after Accounting for Other Marital Demographics? Journal of Cross-Cultural Psychology, 20, 1-15. https://doi.org/10.1177/0022022110362637

[11] Putri, C.Y.Y.P. (2014) Hubungan Persepsi Nilai Anak dengan Jumlah dan Jenis Kelamin Anak yang Diinginkan pada Wanita Usia Subur Pranikah di Perdesaan. Jurnal Biometrika dan Kependudukan, 3, 20-27.

\section{Submit or recommend next manuscript to SCIRP and we will provide best service for you:}

Accepting pre-submission inquiries through Email, Facebook, LinkedIn, Twitter, etc. A wide selection of journals (inclusive of 9 subjects, more than 200 journals) Providing 24-hour high-quality service User-friendly online submission system Fair and swift peer-review system Efficient typesetting and proofreading procedure Display of the result of downloads and visits, as well as the number of cited articles Maximum dissemination of your research work

Submit your manuscript at: http://papersubmission.scirp.org/

Or contact jss@scirp.org 